\title{
Efficacy of chloroquine, chloroquine plus sulphadoxine-pyrimethamine, and amodiaquine for treatment of vivax malaria in Bangka island, Indonesia: a randomized trial
}

\author{
Emiliana Tjitra ${ }^{1}$, Maladi ${ }^{2}$, Budi Prasetyorini ${ }^{1}$, Sri Suprianto ${ }^{3}$, Syahrial Harun ${ }^{1}$, Nurhayati ${ }^{1}$, Eni Yuwarni ${ }^{1}$, \\ Boy Yandri ${ }^{2}$, Ferdinand Laihad ${ }^{3}$, Pascal Ringwald ${ }^{4}$
}

\begin{abstract}
Abstrak
Di Indonesia, malaria Plasmodium vivax resisten klorokuin mengkhawatirkan. Beberapa negara lain juga sudah melaporkan kasus P.vivax resisten klorokuin. Oleh sebab itu, dibutuhkan obat antimalaria alternatif. Ini merupakan penelitian prospektif dan uji perbandingan efikasi terapeutik klorokuin $25 \mathrm{mg}$ basa/kg bb untuk 3 hari (CQ3, n=75), CQ3 plus sulfadoksin-pirimetamin (SP1) berdasarkan dosis pirimetamin 1,25 mg/kg bb dosis tunggal (CQ3+SP1, $n=84)$ dan amodiakuin $25 \mathrm{mg}$ basa/kg bb 3 hari (AQ3, n=83) pada penderita anak dan dewasa dengan malaria vivaks simptomatik. Dalam penelitian ini digunakan sistem penilaian WHO yang terbaru. PCR untuk genotyping juga dilakukan untuk memastikan kesembuhan radikal. Efikasi terapeutik dari CQ3, CQ3+SP1 dan AQ3 pada hari ke 14 sangat tinggi (94.4\%, 97.4\% dan 98.8\%), dan menurun pada hari ke 28 (81.7\%, 87.2\% dan 96.2\% dengan analisis per protokol; setelah di PCR: $78.9 \% .82 .0 \%$ dan 92.5\%; dan 74.7\%, 78.0\% and 90.2\% dengan analisis intention to treat). Hampir semua kasus ACPR (>96\%) menunjukkan perbaikan nilai hematologi. Pembawa gametosit masih diketemukan pada hari ke 7 (2.9\%, $1.3 \%$ dan $1.2 \%)$, hari ke 14 (4.3\%, 1.3\% dan 1.2\%) dan hari ke 28 (6.6\%, 4.2\% dan 0\%) di kelompok CQ3, CQ3+SP1 dan AQ3. Dari ke 3 regimen ini, AQ3 menunjukkan efikasi teraputik yang lebih baik dibandingkan dengan CQ3 dan kombinasi CQ3+SP1 pada hari ke 28. Pemberian primakuin pada awal pengobatan atau pengobatan radikal pada malaria vivaks dapat memperbaiki angka kesembuhan.

(Med J Indones 2008; 17: 96-106)
\end{abstract}

\begin{abstract}
Plasmodium vivax malaria resistant to chloroquine is alarming in Indonesia and has been also reported in other countries. An alternative drug is needed. The study was a prospective evaluation and a comparative study of the therapeutic efficacy of chloroquine $25 \mathrm{mg}$ basel $\mathrm{kg}$ bw for 3 days $(C Q 3, n=75)$, CQ3 plus sulfadoxine-pyrimethamine based on pyrimethamine dosage of $1.25 \mathrm{mg} / \mathrm{kg} \mathrm{bw}$ single dose (SP1) $[C Q 3+S P 1, n=84]$ and amodiaquine $25 \mathrm{mg}$ base/kg bw for 3 days $(A Q 3, n=83)$ in symptomatic vivax malaria patients in children and adults. The new version of 2001 WHO test system was used in this study. PCR for genotyping was also done to validate and confirm the treatment outcomes. The therapeutic efficacy of CQ3,CQ3+SP1 and AQ3 on day 14 were very high (94.4\%, 97.4\% and 98.8\%), and dropped on day $28(81.7 \%, 87.2 \%$ and $96.2 \%$ by evaluable analysis; $78.9 \% .82 .0 \%$ and $92.5 \%$ after confirmation with PCR; and $74.7 \%, 78.0 \%$ and $90.2 \%$ by intention to treat analysis). Most of the ACPR cases (>96\%) showed hematological recovery. Gametocyte carriages were documented on day 7 (2.9\%, 1.3\% and 1.2\%), day 14 (4.3\%, 1.3\% and 1.2\%) and day 28 (6.6\%, 4.2\% and none) in CQ3, CQ3+SP1 and AQ3 groups. Of these 3 regimens, AQ3 showed a better therapeutic efficacy than CQ3 and combined CQ3+SP1 by day 28. Introducing primaquine at the beginning of treatment day or giving a radical treatment in vivax malaria may improve the cure rate. (Med J Indones 2008; 17: 96-106)
\end{abstract}

Keywords: P.vivax, chloroquine, sulfadoxine-pyrimethamine, amodiaquine, artesunate

\footnotetext{
${ }^{1}$ National Institute of Health Research and Development, Ministry of Health, Republic of Indonesia, Jakarta, Indonesia

2 Sungailiat Health Center, Bangka-Belitung Province, Indonesia

${ }_{3}$ Sub-directorate Malaria, Directorate General of Communicable Disease Control and Environmental Health, Ministry of Health, Republic of Indonesia, Jakarta, Indonesia

4 World Health Organization Headquarters, Geneva, Switzerland
}

Bangka island is located between Sumatera and Kalimantan islands (figure 1), an endemic area in Indonesia where malaria is the third common disease with Plasmodium vivax and P. falciparum predominantly. Lots of the people are migrants from South Sumatra and Java as temporary workers in pepper and cooking oil plantations, traditional tin mining, and fisherman. ${ }^{1}$ 
Chloroquine (CQ) resistant P.falciparum has now spread to all provinces, ${ }^{2}$ while CQ resistant $P$. vivax malaria has been detected in a number provinces of Indonesia with efficacy of less than $85 \%$ (16-82\%).-7 Though CQ resistant P.vivax is also reported from other neighboring countries (Vietnam, Myanmar, Thailand, and India), ${ }^{8-11}$ and South America (Brazilia, Columbia, and Peru), ${ }^{12-14}$ CQ is still used as the standard antimalarial drug for treatment of P.vivax malaria globally.

P.vivax (and P.ovale) produces parasite stages in the liver, which may cause relapses and malaria burden to human as well as economic development in affected populations. This burden of vivax malaria is under appreciated. ${ }^{15}$ Moreover, P. vivax can ocassionally result in severe disease with life-threatening, end-organ involvement generally seen with falciparum malaria. ${ }^{16-19}$ The effective antimalarial drug for treatment of P.vivax malaria is an urgent need to prevent the complications and to overcome the global malaria burden, particularly in Indonesia.

Sulfadoxine-pyrimethamine (SP) is relatively still effective for P.falciparum malaria, ${ }^{2}$ and SP is not recommended for monotherapy of $P$. vivax infection because of its slow parasite and fever clearance. ${ }^{20}$ Mutations in the P.vivax dihydrofolate reductase (PvDHFR) have also been found. ${ }^{21-22}$ Despite its slow activity against $P$. vivax, residual antimalarial activity of long half-life, SP will able to suppress relapses. Thus, combination of CQ and SP may improve the cure rate of CQ for P.vivax malaria, and prevent the development of anti-folate resistance in P.falciparum and as well as in P.vivax.

Amodiaquine (AQ) is a 4 amino-quinoline antimalarial drug similar to CQ. In Indonesia, AQ is not available and has never been used. Although in-vitro P. falciparum sensitivity test to this drug had shown resistance, ${ }^{2}$ invivo-study in Africa was found that AQ has a better efficacy than CQ for treatment of uncomplicated falciparum malaria. ${ }^{23}$ In contrary, there is no published amodiaquine data in P.vivax infections. Only a report from Papua New Guinea showed that AQ was more effective than CQ for the treatment ofCQ-resistant vivax malaria. ${ }^{24}$ AQ may be a good alternative antimalarial drug for the treatment of vivax malaria.

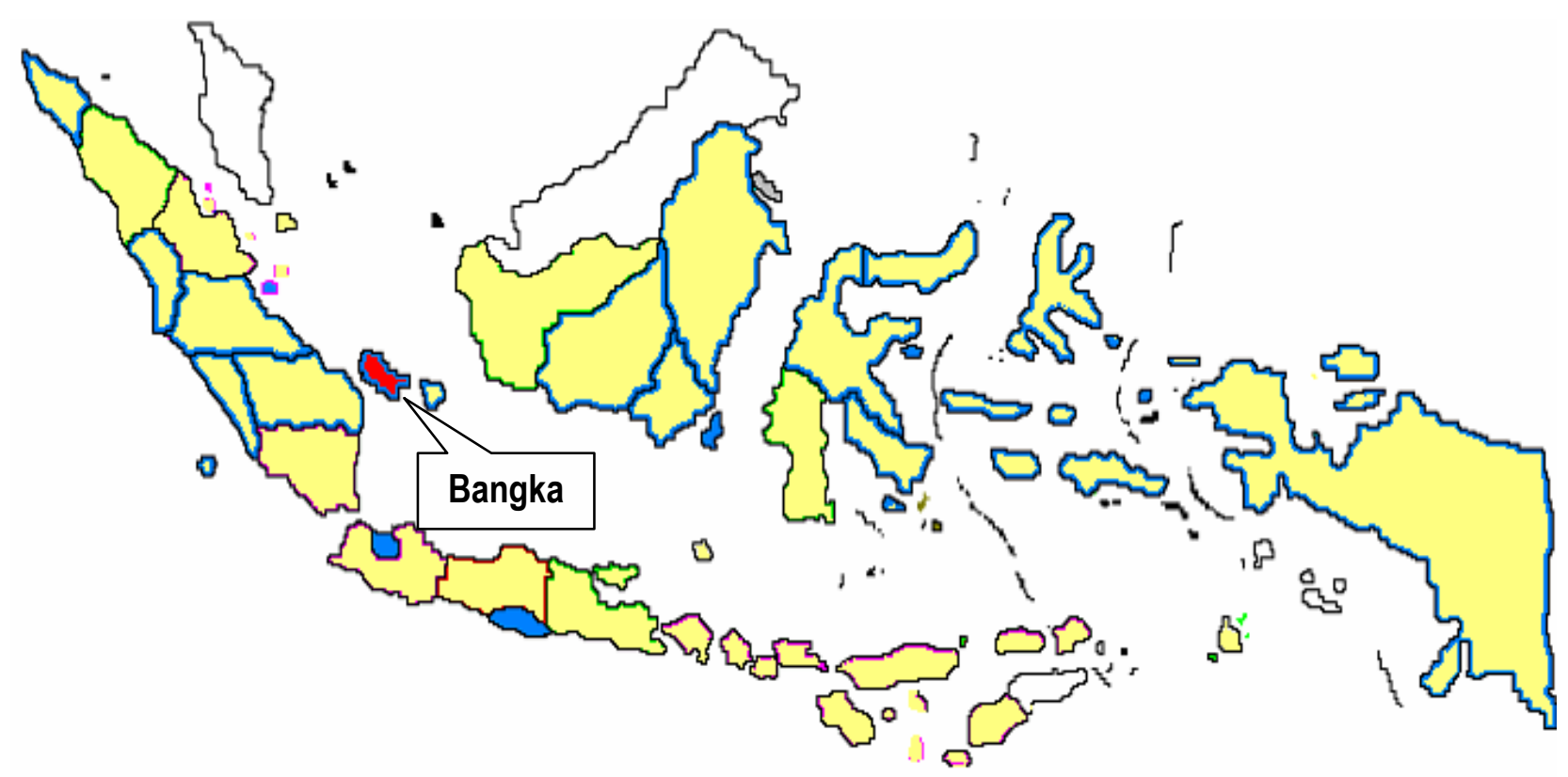

Figure 1. Map of Indonesia where Bangka island with red color 
Similar to P.falciparum, CQ monotherapy will be also no longer effective for P.vivax in Indonesia. Combination of the existing drugs between CQ plus SP is possibly as a practical regimen for both falciparum and vivax malaria. AQ has the advantage over CQ of being more palatable and effective, and inexpensive. Therefore, therapeutic efficacy and tolerance of CQ, CQ plus SP, and $A Q$ in vivax malaria in children and adults has been evaluated for replacing CQ monotherapy as the first-line antimalarial drug and preparing further combined drug for P.vivax infection. In this study, primaquine (PQ) as an anti-relapse for radical treatment of P.vivax was not given together with blood schizontocide drugs, and it was given at the end of study to prevent the bias results. In addition to have more accurate and reliable data, PCR test for genotyping could help to identify resistance or relapse and reinfection cases.

\section{METHODS}

The trial was undertaken from June 2002 to September 2003 at outpatient clinic of Sungailiat Health Center, Bangka Island, Bangka Belitung Province, Indonesia.

This study was reviewed and approved by Scientific Committee and the Ethics Committee of the National Institute of Health Research and Development, Ministry of Health, Jakarta, Indonesia. Thereafter, based on both clearances, the Indonesian Agency of Food and Drug issued a recommendation letter for using unregistered antimalarial drug amodiaquine for this study.

This was a prospective comparative evaluation of the therapeutic efficacy of $\mathrm{CQ}$ alone, $\mathrm{CQ}+\mathrm{SP}$ and $\mathrm{AQ}$ alone based on the new version of 2001 WHO protocol for assessment of therapeutic efficacy of antimalarial drugs in uncomplicated vivax malaria. Patients were randomized according to a computer-generated sequence of random numbers, stratified by age (children and adults), observed for 28 days using a standardised patient drug efficacy record form.

Sample size was calculated by using classical statistical method and anticipated the population proportion with the treatment failure (TF) of $25 \%$ to each regimen (CQ alone, $\mathrm{CQ}+\mathrm{SP}$ and $\mathrm{AQ}$ alone), the highest limit to consider acceptable. ${ }^{25}$ The sample size of a community was at least 72 patients selected in each group within $10 \%$ precision of the true proportion with $95 \%$ confidence level. We added about $10 \%$ for lost to follow-up.

\section{Patients}

A total of 242 uncomplicated vivax malaria patients who attended the outpatient clinic were selected according to the WHO inclusion criteria for the assessment of therapeutic efficacy of antimalarial drugs ${ }^{25}$ and were eligible for enrolment if they were 6 months of age, $P$. vivax monoinfection with the asexual parasite density of $>250 / \mu 1$, a history of fever during the previous 48 hours, the ability to come for the stipulated follow-up visits and easy access to the clinic, and if an informed consent form was signed by the patient or by parent / guardian for children.

The exclusion criteria were severe malnutrition, danger signs of severe and complicated malaria requiring hospitalization, pregnancy or lactation, G6PD deficiency, a history of hypersensitivity reactions or poor tolerance to any other drugs, or febrile diseases or chronic infectious diseases other than malaria, including mixed malaria infection.

\section{Clinical and laboratory examinations}

Clinical history, symptoms and signs were recorded for all patients using a standardised questionnaire form. The trained nurse or midwife took a history and measured the body weight and axillary temperature. The trained study physician then asked complaints using the standardised form, performed a standardized physical examination, and reviewed the nurse or midwife's findings. All patients were re-examined on each day of follow up in the clinic. Close clinical observation for adverse reactions was performed throughout the study period. Follow-up data were recorded in the standardised drug efficacy form.

Blood specimens were collected from a finger prick for thin and thick smears on days $0,1,2,3,7,14,21$, 28 , and on any other day when the patient developed fever or became unwell, and for hemoglobin on days 0,14 and 28. Blood blots were also collected from finger punctures, and on day 0 and any other day when the patient became unwell or developed recurrent parasitemia for PCR and genotyping.

Thick and thin smears were stained with 10\% Giemsa. The trained or certified microscopist who was unaware of the patient's condition read all slides. Parasite density was counted per 200 white blood cells (WBC), and then calculated assuming a WBC of $8,000 / \mathrm{ul}$. A thick smear was considered negative if no parasites were not 
found in at least 100 high power field (hpf). The expert microscopist in Jakarta crosschecked all slides.

Genotyping of the day 0 and day 28 or day of failure were done to identify and distinguish recrudescence or relapse of the original parasite strain from reinfection with a new parasite strain. Recrudescence or relapse was defined as absence of genetic heterogeneity in paired samples, and new infections by heterogeneity of paired samples. Genotyping was undertaken using established technique at Laboratory of Biomedical and Pharmaceutical Research and Development Centre, National Institute of Health Research and Development, $\mathrm{MOH}$, Jakarta, Indonesia. ${ }^{26-27}$

\section{Treatment}

All of the total eligible 242 uncomplicated vivax malaria patients then were treated with treatment allocation and followed up for 28 days. The treatment allocation was concealed by the use of sealed envelopes, which was opened sequentially. In this study, we randomized patients to either open label CQ3 ( $n=75$, Chloroquine, from Kimia Farma, Jakarta, Indonesia, 1 tablet $=150$ $\mathrm{mg}$ base, $25 \mathrm{mg}$ base $/ \mathrm{kg}$ body weight for 3 days, oral single daily dose on days 0,1 , and 2), or to CQ3+SP1 $\left(\mathrm{n}=84, \mathrm{CQ} 3\right.$ plus SP: Fansidar ${ }^{\circledR}$, from Roche, Jakarta, Indonesia, 1 tablet $=500 \mathrm{mg}$ sulfadoxine plus $25 \mathrm{mg}$ pyrimethamine, $25 \mathrm{mg}$ sulfadoxine/ $\mathrm{kg}$ body weight or $1.25 \mathrm{mg}$ pyrimethamine/ $\mathrm{kg}$ body weight, oral single dose on day 0 ), or to AQ3 ( $n=83$, Amoquin ${ }^{\circledR}$ from SmithKline Beecham,1 tablet=200 $\mathrm{mg}$ hydrochloride, $25 \mathrm{mg}$ base/ $\mathrm{kg}$ body weight for 3 days, oral single daily dose on days 0,1 , and 2 . Amoquin $\AA$ was provided by the WHO Geneva).

The study team observed drug administrations in all patients. They all were kept in the clinic for one hour to ensure that they did not vomit. There were no repeated doses in this study. If axillary temperature was $38^{\circ} \mathrm{C}$, paracetamol was given $10 \mathrm{mg} / \mathrm{kg}$ body weight, 8 hourly for 24 hours.

All cases with treatment failure (TF) were treated with oral quinine (QN) $10 \mathrm{mg} / \mathrm{kg}$ body weight/dose, 3 times daily for 7 days, plus a single oral dose of PQ 0.50-0.75 $\mathrm{mg}$ base/kg body weight for uncomplicated falciparum malaria or plus a single daily dose of PQ $0.25 \mathrm{mg}$ base/ $\mathrm{kg}$ body weight for 14 days for uncomplicated vivax malaria. TF cases with danger signs were referred to hospital for intravenous QN as treatment for severe or complicated falciparum malaria. Non-eligible $P$. vivax cases and others malaria were treated as the Indonesian CDC protocol.

On day 28, all Adequate clinical and parasitological response (ACPR) patients except infants were given PQ (primaquine, from Kimia Farma, Jakarta, Indonesia, 1 tablet $=15 \mathrm{mg}$ base) $0.25 \mathrm{mg}$ base $/ \mathrm{kg}$ body weight $/$ day, single daily oral dose for 14 days.

\section{Assessment}

The therapeutic response to CQ3, CQ3+SP1 and AQ3 for uncomplicated vivax malaria were described as on the 2001 WHO general guide for the assessment of therapeutic efficacy of CQ for vivax malaria, and assessed using primary and secondary endpoints. ${ }^{25}$

\section{Data processing}

Data were entered and analysed using Epi-info program. The baseline characteristics or demographic data were described descriptively. Values for age, axillary temperature, and parasite density were presented as means (standard deviations). The key variables for the therapeutic efficacy were TF and ACPR, and gametocyte carriage for vivax malaria. The parameters assessed in those with ACPR are Fever Clearance Time (FCT) and Parasite Clearance Time (PCT), and hematological recovery.

Intent-to-treat (ITT) analysis was also used. In ITT analysis, all patients randomly allocated to a treatment group were retained in analysis whether or not there was an evaluable outcome. Participants withdrawn (but not lost to follow-up) and those with new infections detected by genotyping were included for analysis.

\section{RESULTS}

For 16 months (June 2002 to September 2003), a total of 4,819 febrile patients who attended outpatient clinic at Sungailiat health centre, $23.7 \%$ confirmed as malaria cases by microscopy. There were $530(46.5 \%)$ vivax malaria, and only $45.7 \%$ cases could be enrolled in this study. The 242 elligible symptomatic vivax malaria were randomized: 75 cases in chloroquine (CQ3) group, 84 cases in chloroquine plus sulphadoxine-pyrimethamine (CQ3+SP1) group and 83 cases in amodiaquine (AQ3) group, respectively (Figure 2). 


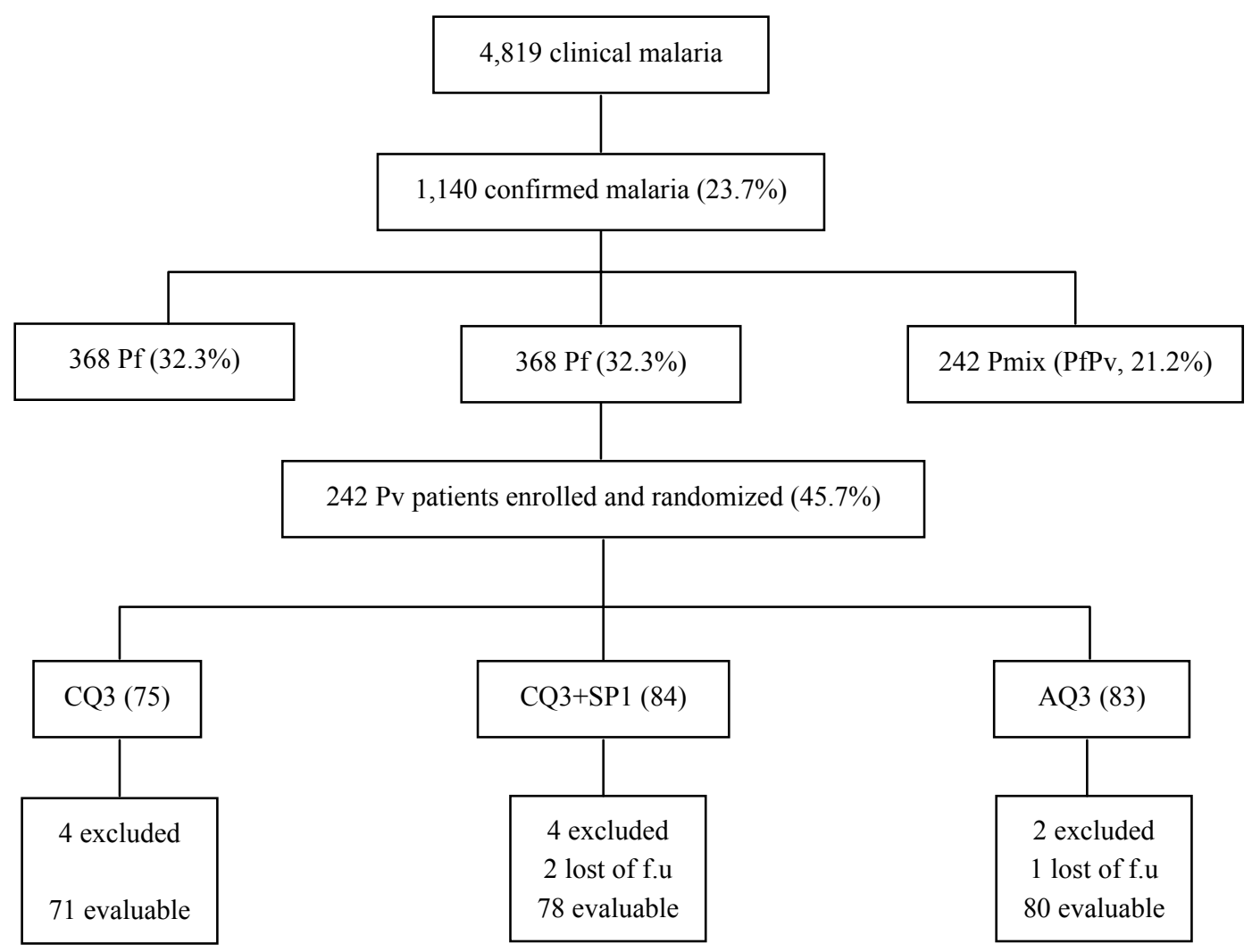

Figure 2. Trial profile, Sungailiat Health Center, Bangka District, Bangka Belitung Province, June 2002 - September 2003

\section{Baseline characteristics of patients with symptomatic vivax malaria}

The age of the study vivax malaria patients ranged from 1 to 71 years old, and most of them were not children under five years old. Only 8 cases of children under five years old were recorded; $2.7 \%$ in CQ3, $4.8 \%$ in $\mathrm{CQ} 3+\mathrm{SP} 1$, and $2.4 \%$ in $\mathrm{AQ} 3$ groups respectively. There were more males $(>60 \%)$ patients, and by chance it was almost significantly higher in AQ3 $(\mathrm{p}=0.06)$. About $70 \%$ were Bangka people, and $19-23 \%$ had been traveling outside Bangka. History of taken antimalarial drugs in the last 4 weeks had been documented in all groups (24.0-33.3\%). On enrolment, all patients had history of fever in the last 48 hours, however only $60.0 \%$ in CQ3, $54.8 \%$ in $\mathrm{CQ} 3+\mathrm{SP} 1$, and $56.6 \%$ in $\mathrm{AQ} 3$ groups had documented axillary temperature of $<37.5^{\circ} \mathrm{C}$. The asexual parasite density of symptomatic vivax malaria patients was ranging from 280 to $22,560 / \mathrm{ul}$, and above $80 \%$ of the patients were as gametocyte carriages. Anemia (hemoglobin $<11 \mathrm{~g} / \mathrm{dl}$ ) were found in most of the study patients, $96.0 \%$ in CQ3, $95.2 \%$ in CQ3+SP1 and $90.4 \%$ in AQ3 groups, respectively (Table 1). 
Table 1. Enrolment characteristics of patients with vivax malaria by treatment regimen, Sungailiat Health Center, Bangka District, Bangka Belitung Province, June 2002 - September 2003

\begin{tabular}{|c|c|c|c|c|}
\hline Characteristic & CQ3 $(n=75)$ & $\mathrm{CQ} 3+\mathrm{SP} 1(\mathrm{n}=84)$ & AQ3 $(n=83)$ & $\mathrm{p}$ \\
\hline Age: mean $\pm \mathrm{SD}$ (range) years & $22.2 \pm 11.3(4-50)$ & $22.8 \pm 13.7(1-71)$ & $22.4 \pm 12.9(1-60)$ & 0.98 \\
\hline Sex: Male : Female (\%) & $48(64.0): 27(36.0)$ & $53(63.1): 31(36.9)$ & $65(78.3): 18(21.7)$ & 0.06 \\
\hline Origin: Bangka (\%) & $53(70.7)$ & $58(69.0)$ & $57(70.0)$ & 0.96 \\
\hline $\begin{array}{l}\text { History of traveling outside } \\
\text { Bangka }(\%)\end{array}$ & $14(18.7)$ & $19(22.6)$ & $19(22.9)$ & 0.77 \\
\hline History of antimalarial use (\%) & $18(24.0)$ & $28(33.3)$ & $22(26.5)$ & 0.39 \\
\hline $\begin{array}{l}\text { Axillary temperature: mean } \pm \mathrm{SD} \\
\text { (range) }{ }^{\circ} \mathrm{C}\end{array}$ & $37.3 \pm 0.9(35.6-39.9)$ & $37.4 \pm 1.1(35.2-40.4)$ & $37.5 \pm 1.1(35.5-41.0)$ & 0.83 \\
\hline $\begin{array}{l}\text { Asexual parasite density: } \\
\text { mean } \pm \mathrm{SD} \text { (range) } / \mu \mathrm{l}\end{array}$ & $3,092 \pm 3,081(280-14.400)$ & $3,760 \pm 4,078(320-22,560)$ & $3,820 \pm 3,769(400-20.460)$ & 0.38 \\
\hline Gametocyte carriage $(\%)$ & $63(84.0)$ & $78(92.9)$ & $73(88.0)$ & 0.22 \\
\hline $\begin{array}{l}\text { Hemoglobin: mean } \pm \text { SD (range) } \\
\text { g/dl }\end{array}$ & $9.2 \pm 0.9(7.6-11.8)$ & $9.5 \pm 0.9(7.4-11.4)$ & $9.4 \pm 1.0(7.2-11.5)$ & 0.30 \\
\hline
\end{tabular}

\section{Therapeutic response of vivax malaria to CQ3, CQ3+SP1 and AQ3}

Of the 242 selected vivax malaria patients, $229(94.6 \%)$ cases were completely evaluated for 28 days. There were $4(5.3 \%)$ CQ3 treated vivax malaria patients were excluded (one had mixed infection on day 0 , one moving from the study site on day 3 , and two could not complete the treatment on day 1), and none lost of follow-up (Table 2). Of those patients who completed follow up days, $18.3 \%$ with treatment failure (3 on day 14: 2 as late clinical failure/LTF and 1 as late parasitological failure/LPF; 4 on day 21 as LCF; and 5 on day 28, 3 as LCF and 2 as LPF) at late R1 level, 94.4\% and 81.7\% with adequate clinical and parasitological response (ACPR) by days 14 and 28, respectively (Table 2 and $3 \mathrm{a}$ and Figure 3). Of the 58 ACPR patients, 86.2\% and $84.5 \%$ were afebrile and aparasitemic on day 2 (Figures 4 and 5), and hematological recovery was found in $96.6 \%$ ACPR patients. Gametocyte carriages were documented $2.9 \%$ on day $7,4.3 \%$ on day 14 , and $6.6 \%$ on day 28 , respectively (Table 2 ).

Of the $84 \mathrm{CQ} 3+\mathrm{SP} 1$ treated vivax malaria patients, 4 cases were excluded: two had mixed infection (one on day 1 and other on day 3 ) and two were failure to complete the treatment due to withdrawal of consent (one on day 1 and other on day 2) (Tables 2 and 3b). There were $2.4 \%$ patients with lost of follow-up (one on day 2 and other on day 21). Of those patients who completed follow up days, $12.8 \%$ with TF: 6 as LCF
( 1 on day 14, 3 on day 21, and 2 on day 28) and 4 as LPF ( 1 on day 7, 1 on day 23, and 2 on day 28) at R1 level ( 1 as early R1 case, and 8 as late R1 cases). There were $97.4 \%$ and $87.2 \%$ ACPR cases on days 14 and 28 (Tables 2 and $3 \mathrm{~b}$ and Figure 3). Of the ACPR cases, $70.6 \%$ and $83.8 \%$ were become afebrile and aparasitemic on day 2 (Figures 4 and 5). Almost all of the ACPR cases (98.5\%) showed hematological recovery. Gametocyte carriages were found in $1.3 \%$, $1.3 \%$ and $4.2 \%$ on days 7,14 , and 28 (Table 2 ).

Of the 83 AQ3 treated vivax malaria patients, $2.4 \%$ were excluded ( 1 failure to complete the treatment on day 2 , and the other one moved from the study site on day 14), and $1.2 \%$ was lost of follow up on day 21 (Table 2). Of the remaining, there were $3.7 \%$ with TF ( 1 as early treatment failure/ETF on day 3 because of moderate nausea and vomiting, and the others as LCF on days 21 and 28 at late R1 level). There were 98.8\% and $96.2 \%$ ACPR cases on days 14 and 28 (Tables 2 and $3 \mathrm{c}$ and Figure 3 ). By day 2, 71.0\% and $89.6 \%$ of ACPR patients were afebrile and aparasitemic (Figures 4 and 5), while hematological recovery were found in $98.7 \%$ of the 77 ACPR patients. There were documented 1.2\%, $1.2 \%$ and none gametocyte carriages in AQ3 treated vivax malaria patients on days 7,14 and 28 (Table 2).

Comparison between of these 3 regimens, AQ3 had slightly more treatment success than CQ3 alone or CQ3 plus SP1 by day 14 , and had significantly $(p=0.02)$ a higher treatment success by day 28 (Table 2). 
There were 228 cases who had a pair blood blots (day 0 and day recrudescent or day 28) were validated by PCR. All the 228 day 0 samples were confirmed as $P$. vivax cases. Samples of all treatment failure cases did not show genetic heterogeneity with paired samples. There were found another 10 treatment failure cases (as false positive cases) from blood blots samples of day 28 and lost follow up (only one of day 21 sample): 2 in $\mathrm{CQ} 3$ group, 4 in CQ3+SP1 group, and 4 in AQ3. One of these 4 additional AQ3 treatment failure cases was a lost follow up case (Table 2). By PCR confirmation, the TF cases of CQ3, CQ3+SP1 and AQ3 became $21.1 \%$ (15 of 71), $24.4 \%$ (14 of 78) and 7.5\% (6 of 80), respectively. However, AQ3 still significantly $(\mathrm{p}=0.05)$ had less treatment failures than other groups (Table 2).
In intention analysis, though the ACPR of all regimens by day 28 were less than in the evaluable analysis, there was still a significantly better therapeutic efficacy of $\mathrm{AQ} 3$ compare to $\mathrm{CQ} 3$ alone and $\mathrm{CQ} 3+\mathrm{SP} 1(\mathrm{p}=0.03)$ (Table 2).

Life-tables of cumulative incidence of therapeutic failure of CQ3, CQ3+SP1 and AQ3 were calculated based on intention to treat cases (excluding lost of follow up and based on PCR confirmation). The therapeutic failures were mostly appeared after day 14 (Tables 3a-c, and Figure 2).

Table 2. Therapeutic efficacy of several regimens in symptomatic vivax malaria patients without or with PCR confirmation, Sungailiat Health Center, Bangka District, Bangka Belitung province, June 2002 - September 2003.

\begin{tabular}{|c|c|c|c|c|}
\hline Therapeutic response & CQ3 $(n=75)$ & $\mathrm{CQ} 3+\mathrm{SP} 1(\mathrm{n}=84)$ & AQ3 $(n=83)$ & $\mathrm{p}$ \\
\hline Excluded $(\%, 95 \% \mathrm{Cl})$ & $4[5.3(1.5-13.1)]$ & $4[4.8(1.3-11.7)]$ & $2[2.4(0.31-8.4)]$ & 0.61 \\
\hline Lost of follow-up $(\%, 95 \% \mathrm{Cl})$ & 0 & $2[2.4(0.3-8.3)]$ & $1[1.2(0.03-6.5)]$ & - \\
\hline \multicolumn{5}{|l|}{ Treatment Failure $(\%, 95 \% \mathrm{CI})$} \\
\hline without PCR confirmation & $13[18.3(9.6-27.8)]$ & $10[12.8(5.9-20.8)]$ & $3[3.7(0.8-10.2)]$ & 0.02 \\
\hline with PCR confirmation & $15[21.1(12.3-32.4)]$ & $14[17.9(10.2-28.3)]$ & $6[7.5(2.8-15.6)]$ & 0.05 \\
\hline \multicolumn{5}{|l|}{$\begin{array}{l}\text { Adequate Clinical and Parasitological } \\
\text { Response (ACPR) }(\%, 95 \% \mathrm{CI})\end{array}$} \\
\hline without PCR confirmation by day 14 & 67 [94.4 (86.2-98.4)] & 76 [97.4 (91.0-99.7)] & $79[98.8(93.2-100)]$ & 0.28 \\
\hline day 28 & $58[81.7(66.2-86.2)]$ & $68[87.2(70.9-88.7)]$ & 77 [96.2 (84.9-97.3)] & 0.02 \\
\hline with PCR confirmation by day 28 & $56[78.9(67.6-87.7)]$ & $64[82.0(71.7-89.8)]$ & 74 [92.5 (84.4-97.2)] & 0.05 \\
\hline $\begin{array}{l}\text { ACPR by Intention to treat analysis } \\
(\mathrm{n} / \mathrm{N}, \%, 95 \% \mathrm{CI})\end{array}$ & $56 / 75[74.7(63.3-84.0]$ & $64 / 82[78.0(67.5-86.4)]$ & $74 / 82[90.2(81.7-95.7)]$ & 0.03 \\
\hline $\begin{array}{l}\text { Fever Clearance Time: mean } \pm \text { SD } \\
\text { (range) days }\end{array}$ & $1.7 \pm 0.7(1-4)$ & $1.8 \pm 1.0(1-4)$ & $1.9 \pm 0.9(1-4)$ & 0.71 \\
\hline $\begin{array}{l}\text { Parasite Clearance Time: mean } \pm \text { SD } \\
\text { (range) days }\end{array}$ & $1.8 \pm 0.7(1-3)$ & $1.9 \pm 0.9(1-4)$ & $1.7 \pm 0.6(1-3)$ & 0.57 \\
\hline $\begin{array}{l}\text { Hematological recovery }(\mathrm{Hb} \text { day } 28>\mathrm{Hb} \\
\text { day } 0, \%, 95 \% \mathrm{CI})\end{array}$ & $56[96.6(63.3-84.0)]$ & $67[98.5(69.6-87.7)]$ & $76[98.7(83.4-96.5)]$ & 0.63 \\
\hline Gametocyte carriage on day $7(\%, 95 \% \mathrm{CI})$ & $2[2.9(0.3-9.3)]$ & $1[1.3(0.03-6.5)]$ & $1[1.2(0.03-6.5)]$ & 0.71 \\
\hline $14(\%, 95 \% \mathrm{CI})$ & $3[4.3(0.8-11.3)]$ & $1[1.3(0.03-6.5)]$ & $1[1.2(0.03-6.5)]$ & 0.37 \\
\hline $28(\%, 95 \% \mathrm{CI})$ & $4[6.6(1.5-13.1)]$ & $3[4.2(0.7-10.1)]$ & 0 & 0.12 \\
\hline
\end{tabular}


Table 3a. Calculating cumulative incidence of therapeutic failure of chloroquine in vivax malaria, Sungailiat Health Center, Bangka District, Bangka Belitung Province, June 2002-September 2003

\begin{tabular}{|c|c|c|c|c|c|}
\hline Day & $\mathrm{N}$ & $\mathrm{i}$ & $\mathrm{W}$ & IR & CIF \\
\hline 0 & 75 & 0 & 1 & 0 & 0 \\
\hline 1 & 74 & 0 & 2 & 0 & 0 \\
\hline 2 & 72 & 0 & 0 & 0 & 0 \\
\hline 3 & 72 & 0 & 1 & 0 & 0 \\
\hline 7 & 71 & 0 & 0 & 0 & 0 \\
\hline 14 & 71 & 4 & 0 & 0.056 & 0.056 \\
\hline 21 & 67 & 4 & 0 & 0.059 & 0.112 \\
\hline 28 & 63 & 7 & 0 & 0.111 & 0.211 \\
\hline $\mathrm{D}$ & \multicolumn{5}{|c|}{$=$ day of test } \\
\hline $\mathrm{N}$ & \multicolumn{5}{|c|}{$=$ number subjects remaining at risk } \\
\hline I & \multicolumn{5}{|c|}{$=$ incident cases of therapeutic failure } \\
\hline $\mathrm{W}$ & \multicolumn{5}{|c|}{$=$ withdrawal cases } \\
\hline IR & \multicolumn{5}{|c|}{$=$ interval risk $\left(\mathrm{i}\left[\mathrm{N}-(\mathrm{w} / 2]^{-1}\right)\right.$} \\
\hline $\mathrm{N}$ & \multicolumn{5}{|c|}{$=$ day of test } \\
\hline $\mathrm{n}-1$ & \multicolumn{5}{|c|}{$=$ the prior interval day test } \\
\hline CIFn & \multicolumn{5}{|c|}{$\begin{array}{l}=\text { cumulative incidence of therapeutic failure } \\
=1-(1-\operatorname{IRn} \times 1-\mathrm{CIFn}-1)\end{array}$} \\
\hline
\end{tabular}

Table 3b. Calculating cumulative incidence of therapeutic failure of combined chloroquine and sulfadoxine-pyrimentahmine in vivax malaria, Sungailiat Health Center, Bangka District, Bangka Belitung Province, June 2002-September 2003

\begin{tabular}{llllll}
\hline Day & N & i & W & IR & CIF \\
\hline 0 & 82 & 0 & 0 & 0 & 0 \\
1 & 82 & 0 & 2 & 0 & 0 \\
2 & 80 & 0 & 1 & 0 & 0 \\
3 & 79 & 0 & 1 & 0 & 0 \\
7 & 78 & 1 & 0 & 0.013 & 0.013 \\
14 & 77 & 1 & 0 & 0.013 & 0.026 \\
21 & 76 & 4 & 0 & 0.053 & 0.078 \\
28 & 72 & 8 & 0 & 0.111 & 0.180 \\
\hline
\end{tabular}

Table 3c. Calculating cumulative incidence of therapeutic failure of amodiaquine in vivax malaria, Sungailiat Health Center, Bangka District, Bangka Belitung Province, June 2002-September 2003

\begin{tabular}{llllll}
\hline Day & $\mathrm{N}$ & $\mathrm{i}$ & $\mathrm{W}$ & $\mathrm{IR}$ & $\mathrm{CIF}$ \\
\hline 0 & 82 & 0 & 0 & 0 & 0 \\
1 & 82 & 0 & 0 & 0 & 0 \\
2 & 82 & 0 & 1 & 0 & 0 \\
3 & 81 & 1 & 0 & 0.012 & 0.012 \\
7 & 80 & 0 & 0 & 0 & 0.012 \\
14 & 80 & 0 & 1 & 0 & 0.012 \\
21 & 79 & 1 & 0 & 0.013 & 0.025 \\
28 & 78 & 4 & 0 & 0.051 & 0.075 \\
\hline
\end{tabular}

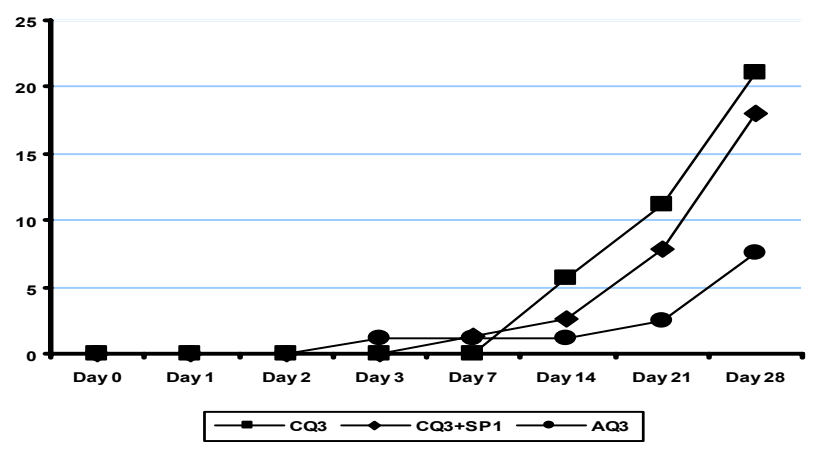

Figure 3. Cumulative incidence of therapeutic failure (\%) of chloroquine, chloroquine plus sulfadoxine-pyrimethamine, and amodiaquine in vivax malaria, Sungailiat Health Center, Bangka District, Bangka Belitung Province, June 2002-September 2003.

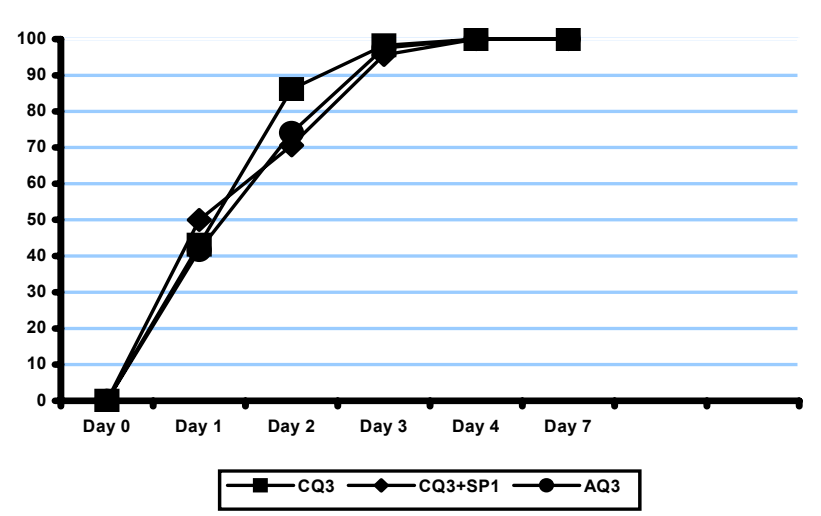

Figure 4. Percent afebrile symptomatic vivax malaria treated with chloroquine, chloroquine plus sulfadoxine-pyrimethamine, and amodiaquine in vivax malaria, Sungailiat Health Center, Bangka District, Bangka Belitung Province, June 2002-September 2003.

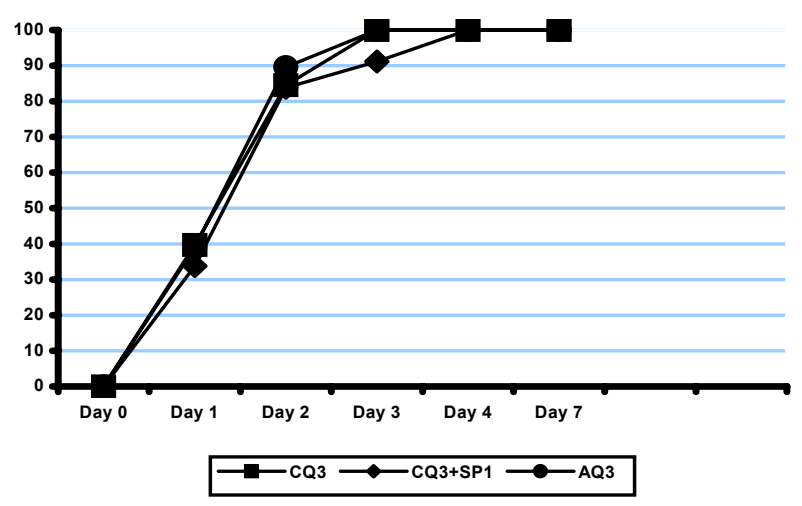

Figure 5. Percent aparasitemic symptomatic vivax malaria treated with chloroquine, chloroquine plus sulfadoxine-pyrimethamine, and amodiaquine in vivax malaria, Sungailiat Health Center, Bangka District, Bangka Belitung Province, June 2002-September 2003 
Table 4. Reported adverse reactions of patients with vivax malaria by treatment regimen, Sungailiat Health Center, Bangka District, Bangka Belitung Province, June 2002 - September 2003.

\begin{tabular}{lcccc}
\hline Adverse reaction & $\mathrm{CQ3}(\mathrm{n}=75)$ & $\mathrm{CQ3}+\mathrm{SP} 1 \mathrm{n}=84)$ & $\mathrm{AQ3}(\mathrm{n}=83)$ & $\mathrm{p}$ \\
\hline Dizziness $(\%, 95 \% \mathrm{CI})$ & 0 & $1[1.2(0.03-6.5)]$ & $4[4.8(1.3-11.9)]$ & 0.08 \\
Nausea $(\%, 95 \% \mathrm{CI})$ & $7[9.3(3.8-18.3)]$ & $7[8.3(3.4-16.4)]$ & $13[15.7(8.6-25.3)]$ & 0.27 \\
Vomiting $(\%, 95 \% \mathrm{CI})$ & $2[2.7(0.3-9.3)]$ & $4[4.81 .3-11.7)]$ & $10[12.0(5.9-21.0)]$ & 0.04 \\
Abdominal pain $(\%, 95 \% \mathrm{CI})$ & $1[1.3(0.03-7.2)]$ & $5[6.0(2.0-13.5)]$ & $8[9.6(4.2-18.1)]$ & 0.08 \\
Diarrhoea $(\%, 95 \% \mathrm{CI})$ & 0 & $1[1.2(0.03-6.5)]$ & 0 & - \\
Dark brown urine $(\%, 95 \% \mathrm{CI})$ & 0 & 0 & $1[1.2(0.03-6.5)]$ & - \\
\hline
\end{tabular}

The adverse reactions to $\mathrm{CQ} 3, \mathrm{CO} 3+\mathrm{SP} 1$ and $\mathrm{AQ} 3$ were mild, and the most common adverse reaction was nausea $(9.3 \%, 8.3 \%$ and $15.7 \%)$. Vomiting was significantly more frequent in AQ3 (12.0\%) than in other groups (CQ3: $2.7 \%$ and CQ3+SP1: $4.8 \%$ ) $(\mathrm{p}=0.04)$. Relatively similar to vomiting, dizziness and abdominal were likely more frequent in AQ3 (4.8\% and $6.0 \%$ ) than in CQ3 group (none and $1.3 \%$ ) and $\mathrm{CQ} 3+\mathrm{SP} 1$ group $(1.2 \%$ and $6.0 \%)(\mathrm{p}=0.08)$. Diarrhoea $(1.2 \%)$ and dark brown urine $(1.2 \%)$ were also reported in CQ3+SP1 and AQ3 groups (Table 4).

\section{DISCUSSION}

This study could collect more clear malaria information and malaria data through training, clarification and close supervision. Compared to the 2001 Bangka Health Profile, a lower Slide Positivity Rate (SPR) was found $(23.7 \%$ vs $42.9-57.6 \%)$ at Sungailiat health centre. ${ }^{1}$ The proportion of Plasmodium vivax was also not as high as recorded in monthly report 2001 (46.5\% vs $>90 \%$ ), and there were also found mixed infection of P. falciparum and P. vivax (21.2\%) which it has almost never been reported before at Sungailiat.

There were a lot of (530) vivax malaria cases during the study period, but less than half of them could enrolled in the study. There were also found quite many mixed infection of $P$. vivax and $P$. falciparum cases. Most of the patients were mobile labors. This may be a cause why many of them could not participate in the study, and a study took a longer time. However only $5.4 \%$ of recruited patients were excluded and lost to follow up.

Bangka is an endemic malaria area, particularly in certain foci such as mining areas, plantation, and coastal areas. There were usually temporary labors at the traditional tin mines, rubber or pepper or cooking oil plantation, or as fishermen. In this study, most of the patients were males, about $70 \%$ were Bangka people, and almost of them were not children. These all support malaria in Bangka is mainly as an occupational health problem.

Although the manifestation of vivax malaria in this study was varied from mild symptom and sign to a very high fever $\left(41^{\circ} \mathrm{C}\right)$. Anemia (hemoglobin $<11 \mathrm{~g} / \mathrm{dl}$ ) was main concerned. Inappropriate treatment by selftreatment (based on history of antimalarial use) or delayed treatment (based on the findings which there were above $80 \%$ gametocyte carriages) may contribute for developing of anemia. Recurring infections from latent liver stages (hypnozoite) may also contribute to chronic anemia. The importance of vivax malaria as a cause of maternal anemia has been described by Nosten et al. ${ }^{28}$

In this study, CQ3 treatment failures were detected by days 14, 21 and 28. These all treatment failure cases had genetic homogeneity with paired samples, and confirmed as not new cases or reinfection cases. It is difficult to distinguish relapse or resistance. They were most likely as relapse cases because the days of recurrence were late and residual CQ in the blood may not enough to protect the first relapse. Moreover, radical treatment with $\mathrm{PQ}$ was postponed to the end of the study. Beside PQ is as anti-relapse, PQ may improve the therapeutic efficacy of chloroquine for treatment of vivax malaria. ${ }^{24}$ These treatment failures may also as recrudescences. CQ blood level may help to clarify these findings, unfortunately CQ blood level was not measured. In this study, the efficacy of CQ3 on day 14 was good (94.4\%). On day 28 , however, the efficacy was drop to $81.7 \%$ (evaluable analysis), $78.9 \%$ (confirmation by PCR) and $74.7 \%$ (intention to treat analysis) in alarming level. P. vivax resistance CQ had also been confirmed elsewhere in Indonesia. ${ }^{3-7}$ Thus, chloroquine combined regimen for treatment of vivax malaria may prevent the development and spreading of 
P. vivax resistant chloroquine and to increase the cure rate. The alternative antimalarial drugs should also to be prepared for treatment of vivax resistance to CQ. Moreover, to have reliable drug efficacy data, at least 28 days follow up should be done. If it is possible, intention to treat analysis and PCR test should be performed to minimize the bias and have a more accurate data. Nevertheless, treatment of vivax malaria with CQ3 resulted rapid fever and parasite clearance and high hematological recovery in ACPR patients.

Similar to CQ3, the therapeutic efficacy of combined CQ3 plus SP1 on day 28 was also less than day 14 because mostly treatment failures were detected on days $>14$. All treatment failure cases confirmed as not new cases or reinfection cases. Probably, they were also as relapse cases. It might CQ3 or SP1, antimalarials long half-life could not protect the first relapse of $P$. vivax malaria. The addition of SP is likely not much improved the efficacy of CQ3 alone. Again, it is difficult to distinguish relapse or resistance. Mutations in the $P$. vivax dihydrofolate reductase (PvDHFR) which have been found in Papuan P. vivax isolates may also the cause of SP failed to improve the cure rate of $\mathrm{CQ} .{ }^{21} \mathrm{CQ}$ blood level may help to confirm whether the recurrent parasitemias was resistant to $\mathrm{CQ}$, but unfortunately we did not perform this measurement. Though, CQ3+SP1 group did not show faster fever and parasite clearance, but this combined regimen had slightly higher proportion of hematological recovery and lower gametocyte carriages than in CQ3 group. A higher means parasite density in CQ3+SP1 group on enrollment may contribute to slower parasite clearance than CQ3 alone.

This is the first study to introduce AQ3 for treatment of vivax malaria in Indonesia even in the world, however, amodiaquine has been used as antimalarial drug in many countries. There were one treatment failure case found on day 3 that could not complete the treatment caused by a moderate nausea and vomiting, and others detected on days $>14$ which probable as relapse cases too. Though, amodiaquine has a similar structure to chloroquine, AQ3 likely had a better cure rate (ACPR on day 28) than CQ3 and CQ3+SP1 ( $p=0.02-0.05)$. The therapeutic efficacy of amodiaquine was good $(>90 \%)$. This regimen also showed rapid fever and parasite clearances including gametocytemia, and a higher hematological recovery. Other studies are needed to confirm these findings.

Artemisinin derivatives has been accepted as a good partner drug for a new paradigma in malaria therapy using an artemisinin based combination particularly for the treatment of P.falciparum resistant multidrug. ${ }^{29}$ Based on the WHO recommendation, since 2004 Indonesian malaria control program has chosen a combination of artesunate-amodiaquine as the first-line for the treatment of falciparum malaria. This combination may also as a good alternative antimalarial drug for the treatment of vivax malaria resistant to chloroquine.

Only few cases in CQ3 group reported adverse reactions. However, more adverse reactions were recorded in $\mathrm{CQ} 3+\mathrm{SP} 1$ and AQ3 than CQ3. Though there is no evidence that higher AQ3 dosage to $>25 \mathrm{mg}$ base $/ \mathrm{kg}$ bw is associated with increased the toxicity, ${ }^{30}$ vomiting should be considered as one of the commonest adverse reaction of AQ3 (15.7\%). However, in this study, all regimens were well tolerated and all the adverse reactions were self -limiting and resolved rapidly except one AQ3 case with moderate nausea and vomiting needs oral antiemetic medicine and then recovery in 2 days.

\section{CONCLUSION}

Of these 3 regimens, AQ3 showed better therapeutic efficacy than CQ3 and combined CQ3+SP1 by day 28. The day 14-therapeutic efficacy is not recommended to use for interpretation. All these regimens were well tolerated. Introducing PQ at the beginning of treatment day or giving a radical treatment in vivax malaria may improve the cure rate. Combination of artesunate and amodiaquine could be as a practical regimen for treatment both uncomplicated falciparum malaria and vivax malaria in a chloroquine resistant area. More studies are needed to support these findings.

\section{Acknowledgement}

We thank the WHO headquarter, Geneva for sponsoring this study. We would like also to thank Prof. Nick White, Faculty of Tropical Medicine, Mahidol University, Bangkok, Thailand for suggestion to trial amodiaquine. Our extended thank to Drs. Pascal Ringwald from WHO-Geneva, Arbani PR from WHO-SEARO-New Delhi, Astuti Suparmanto, Sumarjati Arjoso, Agus Suwandono and Ingerani from NIHRD-MOH-Jakarta, Umar Fahmi and Thomas Suroso and Ferdinand Laihad from CDC-MOH-Jakarta, and Amri Alamsyah and Erma Lizani from Bangka Belitung Health OfficePangkalpinang and Sungailiat for supporting and helping this study. 


\section{REFERENCES}

1. Dinas Kesehatan Kabupaten Bangka. Profil Kesehatan Kabupaten Bangka tahun 2001. (Gambaran Situasi Kesehatan Tahun Kerja 2000): Bangka Sehat 2008. Dinas Kesehatan Kabupaten Bangka, Provinsi Bangka Belitung, Sungailiat, Bangka, 2001.

2. Tjitra, E. et al. Evaluation of antimalarial drugs in Indonesia. Bulletin of Health Studies, 1997, 25(1): 27-58.

3. Baird JK, Wiady I, Fryauff DJ, Sutamihardja A, Leksana B, Widjaya H, Kysdarmanto, and Subianto B In vivo resistance to chloroquine by Plasmodium vivax and Plasmodium falciparum at Nabire, Irian Jaya, Indonesia. Am J Trop Med Hyg, 1997, 56(6): 627-31.

4. Fryauff DJ, Sekartuti, Mardi A, Masbar S, Patipelohi R, Leksana B, Kain KC, Bangs MJ, Richie TL, and Baird JK. Chloroquine-resistant Plasmodium vivax in transmigration settlements of west Kalimantan, Indonesia. Am J Trop Med Hyg, 1998, 59(4): 513-18.

5. Tjitra, E. Improving the diagnosis and treatment of malaria in Eastern Indonesia. Thesis PhD, 2001.

6. Fryauff DJ, Leksana B, Masbar S, Wiady I, Sismadi P, Susanti AI, Nagesha HS, Syafruddin, Atmosoedjono S, Bangs MJ, Baird JK. The drug sensitivity and transmission dynamics of human malaria on Nias Island, North Sumatra, Indonesia. Ann Trop Med Parasitol, 2002, 96(5):447- 62.

7. Maguire JD, Lacy MD, Sururi, Sismadi P, Krisin, Wiady I, Leksana B, Bangs MJ, Masbar S, Susanti I, Basuki W, Barcus MJ, Marwoto $\mathrm{H}$, Edstein MD, Tjokrosonto $\mathrm{S}$, Baird JK. Chloroquine or sulfadoxine-pyrimethamine for the treatment of uncomplicated Plasmodium falciparum malaria during an epidemic in Central Java, Indonesia. Ann Trop Med Parasitol , 2002, 96(7):655-68.

8. Phan GT, de Vries PJ, Tran BQ, Le HQ, Nguyen NV, Nguyen TV, Heisterkamp SH, Kager PA. Artemisinin or chloroquine for blood stages Plasmodium vivax malaria in Vietnam. Trop Med Int Health, 2002, 7(10):858-64.

9. Marlar T, Myat Phone K, Aye Yu S, Khaing Khaing G, Ma $\mathrm{S}$, Myint O. Development of resistance to chloroquine by Plasmodium vivax in Myanmar. Trans R Soc Trop Med Hyg, 1995, 89: 307-8.

10. Pukrittayakamee S, Chantra A, Simpson JA, Vanijanonta S, Clemens R, Looareesuwan S, and White NJ. Therapeutic responses to different antimalarial drugs in vivax malaria. Antimicrob Agents Chemother, 2000, 44(5):1680-5.

11. Yadav RS, Ghosh SK. Radical curative efficacy of five-day regimen of primaquine for treatment of Plasmodium vivax malaria in India. J Parasitol, 2002, 88(5):1042-4.

12. Baird JK, Tiwari T, Martin GJ, Tamminga CL, Prout TM, Tjaden J, Bravet PP, Rawlins S, Ferrel M, Carucci D, Hoffman SL. Chloroquine for the treatment of uncomplicated malaria in Guyana. Ann Trop Med Parasitol, 2002, 96(4): 339-48.

13. Castillo CM, Osorio LE, Palma GI. Assessment of therapeutic response of Plasmodium vivax and Plasmodium falciparum to chloroquine in a Malaria transmission free area in Columbia. Mem Inst Oswaldo Cruz, 2002, 97(4):559-62.
14. Ruebush TK, Zegarra J, Cairo J, Andersen EM, Green M, Pillai DR, Marquino W, Huilca M, Arevalo E, Garcia C, Solary L, Kain KC. Choloroquine-resistant Plasmodium vivax malaria in Peru. Am J Trop Med Hyg, 2003, 69(5): 548-52.

15. Hay SI, Guerra CA, Tatem AJ, Noor AN, and Snow RW. The global distribution and population at risk of malaria: past, present, and future. Lancet, 2004, 4:327-36.

16. Tanios MA, Kogelman L, McGovern B, Hassoun PM. Acute respiratory distress syndrome complicating Plasmodium vivax malaria. Crit Care Med, 2001, 29(3):665-7.

17. Oh MD, Shin H, Shin D, Kim U, Lee S, Kim N, Choi MH, Chai JV, Choe K. Clinical features of vivax malaria. Am J Trop Med Hyg, 2001, 65(2):143-6.

18. Beg MA, Khan R, Baig SM, Gulzar Z, Hussain R, Smego RA Jr. Cerebral involvement in benign tertian malaria. Am J Trop Med Hyg, 2002, 67(3) :230-2.

19. Prakash J, Singh AK, Kumar NS, Saxena RK. Acute renal failure in Plasmodium vivax malaria. Assoc Physicians India, 2003, 51:265-7.

20. Darlow B. et al. Sulfadoxine-pyrimethamine for the treatment of acute malaria in children in Papua New Guinea. II. Plasmodium vivax. Am J Trop Med Hyg, 1982, 3(1): 10-13.

21. Tjitra E, Baker J, Suprianto S, Cheng Q, Anstey NM. Therapeutic efficacies of artesunate-sulfadoxine-pyrimethamine and chloroquine-sulfadoxine-pyrimethamine in vivax malaria. Pilot studies: Relationship to Plasmodium vivax dhfr mutations. Antimicrob Agents Chemother, 2002, 46(12):3947-53.

22. Imwong M, Pukrittayakamee S, Renia L, Letourneur F, Charlieu JP, Leartsakulpanich U, Looareesuwan S, White NJ, Snounou G. Novel point mutations in the dihydrofolate reductase gene of Plasmodium vivax: evidence for sequential selection by drug pressure. Antimicrob Agents Chemother, 2003, 47: 1514-21.

23. Brasseur $\mathrm{P}$ et al. Amodiaquine remains effective for treating uncomplicated malaria in west and central Africa. Trans Roy Soc Trop Med Hyg, 1999, 93(6): 645-50.

24. Rieckman KH. Monitoring the response of malaria infections to treatment. Bulletin of the WHO, 1990, 68: 759-60.

25. World Health Organization. A general guide for the assessment of therapeutic efficacy of chloroquine for vivax malaria. World Health Organisation. Geneva, 2001b.

26. Craig AA, Kain KC. Molecular analysis of strains of Plasmodium vivax from paired primary and relapse infections. J Infec Dis, 1996, 174: 373-9.

27. Kain KC, Brown AE, Mirabelli L, and Webster HK. Detection of Plasmodium vivax by polymerase chain reaction in a field study. J Infect Dis, 1993, 168: 1323-6.

28. Nosten F. et al. Effects of Plasmodium vivax malaria in pregnancy. Lancet, 1999, 354: 546-9.

29. WHO. Antimalarial drug combination therapy. Report of a WHO Informal Consultation 4-5 April 2001. WHO/CDS/ RBM/2001.35. World Health Organization. Geneva. 2001b

30. WHO. The use of antimalarial drugs. Report of a WHO Informal Consultation, 13-17 November 2000. WHO/CDS/ RBM/2001.33. World Health Organization. Geneva, 2000. 